$11-1995$

\title{
The Magnitude And Persistence Of Soil No, N2O, Ch4, And Co, Fluxes From Burned Tropical Savanna In Brazil
}

M Poth

Iris C. Anderson

Virginia Institute of Marine Science

et al

Follow this and additional works at: https://scholarworks.wm.edu/vimsarticles

Part of the Environmental Sciences Commons, and the Terrestrial and Aquatic Ecology Commons

\section{Recommended Citation}

Poth, M; Anderson, Iris C.; and al, et, "The Magnitude And Persistence Of Soil No, N2O, Ch4, And Co, Fluxes From Burned Tropical Savanna In Brazil" (1995). VIMS Articles. 1408.

https://scholarworks.wm.edu/vimsarticles/1408

This Article is brought to you for free and open access by the Virginia Institute of Marine Science at W\&M ScholarWorks. It has been accepted for inclusion in VIMS Articles by an authorized administrator of W\&M ScholarWorks. For more information, please contact scholarworks@wm.edu. 


\title{
The magnitude and persistence of soil $\mathrm{NO}, \mathrm{N}_{2} \mathrm{O}, \mathrm{CH}_{4}$, and $\mathrm{CO}_{2}$ fluxes from burned tropical savanna in Brazil
}

\author{
Mark Poth, ${ }^{1}$ Iris Cofman Anderson, ${ }^{2}$ Heloisa Sinatora Miranda, ${ }^{3}$ \\ Antonio Carlos Miranda, ${ }^{3}$ Philip J. Riggan ${ }^{1}$
}

\begin{abstract}
Among all global ecosystems, tropical savannas are the most severely and extensively affected by anthropogenic burning. Frequency of fire in cerrado, a type of tropical savanna covering $25 \%$ of Brazil, is 2 to 4 years. In 1992 we measured soil fluxes of $\mathrm{NO}, \mathrm{N}_{2} \mathrm{O}, \mathrm{CH}_{4}$, and $\mathrm{CO}_{2}$ from cerrado sites that had been burned within the previous 2 days, 30 days, 1 year, and from a control site last burned in 1976 . NO and $\mathrm{N}_{2} \mathrm{O}$ fluxes responded dramatically to fire with the highest fluxes observed from newly burned soils after addition of water. Emissions of $\mathrm{N}$-trace gases after burning were of similar magnitude to estimated emissions during combustion. NO fluxes immediately after burning are among the highest observed for any ecosystem studied to date. These rates declined with time after burning and had returned to control levels 1 year after the burn. An assessment of our data suggested that tropical savanna, burned or unburned, is a major source of $\mathrm{NO}$ to the troposphere. Cerrado appeared to be a minor source of $\mathrm{N}_{2} \mathrm{O}$ and a sink for atmospheric $\mathrm{CH}_{4}$. Burning also elevated $\mathrm{CO}_{2}$ fluxes, which remained detectably elevated 1 year later.
\end{abstract}

\section{Introduction}

One of the keys to understanding global atmospheric change is to understand the interactions between land management practices and the influence of these actions on the magnitude and direction of ecosystem trace gas exchange. Many of the atmospheric trace gases of interest are the direct or indirect products of biological activity. Consequently, tropical biomes of high biological activity are important contributors to the global trace gas budget. The emissions data available on what are a wide variety of tropical ecosystems supports the importance of tropical ecosystems as sources of $\mathrm{NO}, \mathrm{N}_{2} \mathrm{O}$ [Keller et al., 1983; Keller et al., 1986; Seiler and Conrad, 1987; Kaplan et al., 1988; Goreau and de Mello, 1988; Johansson and Sanhueza, 1988; Luizao et al., 1989; Garcia-Mendez et al., 1991] and methane [Keller et al., 1986; Hao et al., 1988]. An understanding of how biosphere/atmosphere trace gas exchanges are modified by various land use practices is lacking [Keller et al., 1992; Davidson et al., 1993]. Without such data, projections or assessments cannot be made of the numerous land use options available. We need

\footnotetext{
'U.S. Department of Argiculture, Forest Service Research, Riverside, California.

${ }^{2}$ Virginia Institute of Marine Science, College of William and Mary, Gloucester point, Virginia.

${ }^{3}$ Departmento do Ecológia, Universidade de Brasília, Brasília, Brasil.

Copyright 1995 by the American Geophysical Union.
}

Paper number 95GB02086.

0886-6236/95/95GB-02086\$10.00 more trace gas exchange data and a better understanding of the mechanisms involved in order to select optimal strategies for mitigating emissions.

Disturbance can greatly alter soil processes and trigger changes in the emission rates of important trace gases. For example, grassland fertilizations can stimulate $\mathrm{N}_{2} \mathrm{O}$ emissions and depress methane uptake [Mosier et al., 1991]. This is the result of the stimulation of soil nitrification and denitrification processes and the inhibiting effects of ammonium on the biological oxidation of methane. Flooding caused by new reservoirs has increased $\mathrm{CO}_{2}$ and $\mathrm{CH}_{4}$ emissions [Rudd et al., 1993] by changing oxygen availability to what used to be forest soils. Fire in California chaparral dramatically stimulated $\mathrm{NO}$ and $\mathrm{N}_{2} \mathrm{O}$ emissions for over 6 months [Anderson and Poth, 1989] by converting nitrogen into more available forms for nitrification and temporarily reducing competition for nitrogen from plant uptake. Conversely, in burned tall grass prairie, little $\mathrm{N}_{2} \mathrm{O}$ was released from burned soils because of uptake by the surviving grasses [Groffman et al., 1393]. Fire is certainity a potentit fớce in the trôpics [Crutzen and Andreae, 1990; Riggan et al., 1993], yet information on the influence of fire on soil emissions of important trace gases is limited [Luizao and Matson, 1989; Hao et al., 1988].

Cerrado, a tropical vegetation type unique to South America, covers 2 million $\mathrm{km}^{2}$ or about $25 \%$ of Brazil. Fires set by man or by lightning are common in the dry season and have been occurring in these ecosystems for thousands of years [Goodland, 1971]. Cerrado is made up of diverse plant communities covering a continuum from 
open tropical grassland to savanna (campo limpio) to cerradão, a closed canopy semideciduous forest. Five distinct plant communities are recognized [Goodland, 1971; Coutinho, 1982]. The gradient of cerrado vegetation has been hypothesized to follow gradients in soil fertility and fire use. Fire is very common in grasslands and savannas but is a rare occurrence in the mature closed canopy cerradão forests [Goodland, 1971]. Fuel characteristics and direct fire emissions rates have been reported for cerrado by Ward et al. [1992]. This paper reports the first measurements of trace gas fluxes from cerrado soils and the effects of burning on changing flux rates, and also assesses the importance of fire disturbance of tropical savanna on the global budget of trace gases.

\section{Methods}

\section{Study Site}

Our study was conducted within the research and ecological reserve operated by the Instituto Braseleiro de Geografia e Estatística (IBGE), located $20 \mathrm{~km}$ south of Brasilia, District Federal (15 $\left.55^{\prime} 58^{\prime \prime} \mathrm{S}, 47^{\circ} 51^{\prime} 02^{\prime \prime} \mathrm{W}\right)$. The climate is tropical (Köppen's Aw) with mean annual precipitation of $1100-1600 \mathrm{~mm}$. This area of the tropics is characterized by distinct wet (October to March) and dry (April to September) seasons with $90 \%$ of the precipitation falling in the wet season. The mean relative humidity is $64 \%$, but it can be as low as $18 \%$ during the driest periods. The annual mean maximum temperature is $25^{\circ} \mathrm{C}$ and the annual mean minimum temperature $16^{\circ} \mathrm{C}$ (climate data courtesy of the Reserva Ecológica, IBGE, 1980-1989). Soils are dystrophic, deep, and well-drained red latisols.

Current research at IBGE has been carried out in three experimental sites with different physiognomic forms: cerradão, closed canopy semideciduous forest; cerrado, a dense scrub of shrubs and trees (in a strict sense), and campo sujo, a grassland with scattered shrubs [Goodland, 1971]. Plots are burned every 4 years (in August), or every 2 years (in either June, August, or September). Long-term control plots have not burned since 1976. Plot size ranges from 1 to $5 \mathrm{ha}$. The overall design includes 37 plots.

The work we report on here was done during late August of 1992. Burning was carried out by the Reserva Ecológica - IBGE technicians in conjunction with Universidade de Brasília staff. Fires were usually started at 1400 LT. Fires spread quickly and typically were completed within $30 \mathrm{~min}$.

We measured fluxes of $\mathrm{NO}, \mathrm{N}_{2} \mathrm{O}, \mathrm{CH}_{4}$, and $\mathrm{CO}_{2}$ from cerrado sites that had been burned within the previous 2 days. We also made measurements on plots $\mathbf{3 0}$ days and 1 year after burning and from long-term control plots that have remained unburned since 1976. Although we made measurements at replicate plots, all of these are within the Reserva Ecológica - IBGE.

\section{Plant Biomass and Fuel Consumption}

To partially characterize the fire at these sites, we measured total fuel consumption during the fire by determining the plant biomass before and after burning. On the basis of previous prescribed fire experiments, we have defined fuel for the cerrado simply as the living or dead parts of the vegetation found from the soil surface to a height of $2 \mathrm{~m}$. Tree trunks and stems with a diameter greater than $6 \mathrm{~mm}$ are excluded. To estimate fuel, five transect lines of $15 \mathrm{~m}$ were established in each plot. For each transect, five subplots $(25 \times 25 \mathrm{~cm})$ at $3-\mathrm{m}$ intervals were used to sample the fuel. All fuel within the subplot was clipped at ground level, and together with the litter on the soil surface, taken to the laboratory. In the laboratory, fuel was separated into live and dead grasses, leaves, and stems. The fuel was dried at $80^{\circ} \mathrm{C}$ for 48 hours, allowed to cool, and weighed. For higher shrubs and trees, the fuel was sampled in a subplot $1-\mathrm{m}$ wide, 5-m long, and 2-m high in the middle of each transect. After the fire, a similar transect was used to collect and estimate the amount of unburned fuel.

\section{Flux Measurements}

Fluxes of $\mathrm{NO}, \mathrm{N}_{2} \mathrm{O}, \mathrm{CH}_{4}$, and $\mathrm{CO}_{2}$ were measured using a closed box flux technique [Anderson and Levine, 1987]. One day prior to making flux measurements at each plot, six stainless steel frames, covering an area of 0.581 $\mathrm{m}^{2}$ were driven $2.5 \mathrm{~cm}$ into the soil. In order to measure fluxes of either $\mathrm{CO}_{2}$ or NO, a Teflon-lined, expanded-cell polycarbonate box fitted with a fan and with a total volume of $150.5 \mathrm{~L}$ (including the frame volume) was placed over the frame. The base of the flux box was sealed to the frame via a Teflon-covered foam lining. Two openings $(0.64 \mathrm{~cm})$ in the top of the flux box prevented pressure changes from developing during sampling. For $\mathrm{N}_{2} \mathrm{O}$ and $\mathrm{CH}_{4}$ measurements, a flux box with a total volume of 76.9 $\mathrm{L}$ was used in order to increase sensitivity. Because we made measurements during the dry season, soils were relatively dry. After measuring trace gas flux rates of dry soils, we added distilled water equivalent to a $1-\mathrm{cm}$ rainfall. After $30 \mathrm{~min}$, gas flux measurements were repeated. We sampled a new plot each day.

\section{Inhibitors and Soil Amendments}

To assess the roles of different microbial communities in producing the observed fluxes of trace gases, we employed two nitrification inhibitors: acetylene and allylthiourea (ATU). Acetylene was added to the flux box to a concentration of $1 \%$ and allowed to react with the soil for 1 hour. The flux cover was then removed and gas allowed to disperse for $10 \mathrm{~min}$. This was to done to eliminate acetylene interference with NO measurements and 
achieve inhibition of nitrification. A solution of $200-\mu M$ ATU was added to the soil 1 hour before measurements began. The amount added was equivalent to $1 \mathrm{~cm}$ of rainfall.

Soils in the unburned plots might have been substrate limited for $\mathrm{NO}$ or $\mathrm{N}_{2} \mathrm{O}$ production. To test for this, unburned soils were amended with 10-m $M-\mathrm{N}$ ammonium chloride or potassium nitrate solutions equivalent to $1 \mathrm{~cm}$ of rainfall 1 hour prior to initial measurements.

\section{Analysis of Carbon Dioxide}

Immediately upon setting the flux chamber on its frame, $\mathrm{CO}_{2}$ was analyzed in sample air over a 3-min period using a LiCor 6200 photosynthesis system with integrated infrared gas analyzer and data system. (All manufacturer and brand names are used for information only. No endorsement is intended.) The instrument was modified by removing the cuvette and substituting the flux box cover system described above as the input source. Standard errors for $\mathrm{CO}_{2}$ fluxes using this system were $<1 \%$ of the rates measured.

\section{Analysis of Nitric Oxide}

Immediately following the 3-min sampling period for $\mathrm{CO}_{2}$, the sample stream was switched to a system for analysis of NO, which was detected over an 8-min period using a Luminox, nitrogen dioxide $\left(\mathrm{NO}_{2}\right)$ detector (Model LMA-3, Scintrex-Unisearch, Toronto, Canada) as described by Anderson and Poth [1989]. Sample air from the flux box, pumped at approximately $2.8 \mathrm{~L} \mathrm{~min}^{-1}$ by a Teflon bellows and a battery-operated pump, was dried by passage through nafion tubing (Type 815, Dupont perfluorinated polymer, Perma Pure, Inc., Toms River, N.J.) packed in indicating silica gel. NO in the dried sample gas was converted to $\mathrm{NO}_{2}$ by passage through a tube $(7.6 \mathrm{~cm})$ containing $10 \%$ chromium trioxide on firebrick $(30 / 60$ mesh, Chromosorb P, Altech) before being pumped to a tee inlet on the LMA-3 $\mathrm{NO}_{2}$ detector, which then sampled the gas stream at the rate of $1.5 \mathrm{~L} \mathrm{~min}^{-1}$. A three-way valve, which switched flow of sample air from the converter tube to a blank tube, allowed measurement of either background $\mathrm{NO}_{2}$ in sample air (following passage through the blank tube) or $\mathrm{NO}+\mathrm{NO}_{2}$ (following passage through the converter tube). The chromium trioxide/firebrick was replaced whenever we observed a decrease in converter efficiency during calibration. Calibrations and measurements of flow rates through the pumping system and the LMA-3 were performed at the beginning and at the end of each day of data collection. During calibration, the LMA-3 was zeroed with room air which was passed first through a column containing pellets of alumina coated with $\mathrm{KMnO}_{4}$ (Purafil, Southeastern Engineering Co.,
Midlothian, Va). This column reduces the background NO in room air to approximately 2 to 4 ppbv (parts per billion by volume) and obviates the need for transporting cylinders of zero air to field sites. For calibration NO (approximately 9 ppmv, Scott Environmental Technology, Plumsteadville, $\mathrm{Pa}$.) was mixed with room air (after passage through $\mathrm{KMnO} 4$ coated alumina) providing known concentrations of NO ranging from 20 to $50 \mathrm{ppbv}$. Gas flows were controlled with mass flow controllers (Tylan, model FC 280). Fluxes of NO were calculated from the slope of the regression line of NO versus time $(4-8 \mathrm{~min})$ after correction of the NO concentration for dilution during sampling.

\section{Analysis of $\mathrm{CH}_{4}$ and $\mathrm{N}_{2} \mathrm{O}$}

For analysis of $\mathrm{CH}_{4}$ and $\mathrm{N}_{2} \mathrm{O}$, samples were taken through a septum on the top of the flux box every $20 \mathrm{~min}$ for 1 hour using $60-\mathrm{mL}$ disposable plastic syringes with rubber plunger tips and fitted with three-way stopcocks. Samples were analyzed for $\mathrm{N}_{2} \mathrm{O}$ using a gas chromatograph (Hewlett Packard, model 5890, Palo Alto, Calif.) with electron capture detector and 10-port valve allowing backflushing of the column following each sample run. The detector temperature was $330^{\circ} \mathrm{C}$, oven temperature was $50^{\circ} \mathrm{C}$, the column was a $2-\mathrm{m}$ porapak $Q$, and argon plus $5 \%$ methane was the carrier gas at a flow rate of $30 \mathrm{~mL}$ min-1. $\mathrm{CH}_{4}$ in these samples was measured by gas chromatography with a flame ionization detector. The column was 2-m stainless-steel, containing molecular sieve $5 \AA$. Detector temperature was $250^{\circ} \mathrm{C}$ and the column $70^{\circ} \mathrm{C}$. Helium was used as the carrier gas at a flow rate of $30 \mathrm{~mL} \mathrm{~min}^{-1}$.

\section{KCl-Extractable Soil $\mathbf{N H}_{4}{ }^{+}, \mathbf{N O}_{2}^{-}$, and $\mathrm{NO}_{3}^{-}$}

At the study site, composite samples (five subsamples each) were taken from the top 2-cm of soil both around each of the flux box frames and within each frame at the completion of the experiment. These samples were taken immediately after the completion of flux measurements. Soils were air dried, sealed in whirl-pak bags, and extracted with $2-M \mathrm{KCl}$ upon return to the laboratory, using a modification of the technique of Keeney and Nelson [1982]. A 5-g sample of soil was weighed into a 50-mL screw cap centrifuge tubc. The tube was sealed after adding 50 -iml of $2 M \mathrm{KCl}$ and mixed with a wrist action shaker for 1 hour. The tube was then centrifuged and the supernatant used for analysis. Ammonium was determined colorimetrically by an automated indophenol method (Technicon Industrial Method 780-86T), nitrite via diazotization (Technicon Industrial Method 784-86T), and nitrate + nitrite by copperized cadmium reduction in combination with diazotization (Technicon Industrial Method 818-86T), using a Technicon Traacs autoanalyzer, Model 800 (Technicon Corporation, Terrytown, N.Y). 


\section{Percent Moisture}

Samples for analysis of percent moisture were taken as described above, stored for less than $\mathbf{3 0} \mathrm{min}$ in whirl-pak bags, weighed, and dried to constant weight at $105^{\circ} \mathrm{C}$. Percent moisture is reported as percent of dry weight.

\section{Measured pH}

A 1:1 soil water paste was prepared with glass-distilled water and allowed to stand for 1 hour. The soil was then stirred and the $\mathrm{pH}$ measured using a Beckman, model $71 \mathrm{pH}$ meter with temperature compensation.

\section{Soil and Air Temperatures}

During each flux measurement, temperature was measured both within the flux box at approximately half height and in the soil at a depth of $2 \mathrm{~cm}$. A National Institute of Standards and Technology (NIST)-calibrated thermometer equipped with thermistor probes was used.

\section{Enumeration of Autotrophic Nitrifiers}

Autotrophic nitrifier populations were estimated using a five-tube most probable number (MPN) procedure [Schmidt and Belser, 1982]. After inoculation, tubes were incubated at room temperature for 30 days. Positive tubes were those containing nitrate and/or nitrite, determined colorimetrically [Schmidt and Belser, 1982].

\section{Statistics}

For measured variables, normal probability plots were used to assess the distribution of the data. To determine the relationships between measured soil parameters and trace gas fluxes, we used regression analysis and calculated Pearsons coefficient of determination and associated $p$ values. Because of observed nonlinearity in probability plots and to be conservative in testing for differences between burn treatments and water amendments, we used the Kurskal-Wallis one-way analysis of variance, a nonparametric technique. All analyses were performed with the Systat (V.5.1) package for Macintosh computers [Wilkinson, 1989].

\section{Results}

\section{Plant Biomass and Fuel Consumption}

The measured (all leaves and stems less than $6 \mathrm{~mm}$ ) plant biomass plot averages in campo sujo and cerrado, in a strict sense, stands varied, respectively, from 0.67 (SD 0.08 ) $\mathrm{kg} \mathrm{m}^{-2}$ to 0.082 (SD 0.09) $\mathrm{kg} \mathrm{m}^{-2}$, and from 0.75 (SD 0.09) $\mathrm{kg} \mathrm{m}^{-2}$ to 1.24 (SD 0.13 ) $\mathrm{kg} \mathrm{m}^{-2}$. In the cerrado areas, grasses were less than $30 \%$ of the total fuel load and dead leaves from the litter layer accounted for $36-39 \%$. The fire consumed $81-98 \%$ of the fuel in campo sujo plots and $68-97 \%$ in the cerrado plots. Remaining biomass consisted mainly of larger stems in burned areas with occasional unburned islands accounting for the remainder.

\section{Soil Chemical Responses to Fire}

The fire had a dramatic effect on soil chemistry (Table 1). Burning increased the concentration of extractable ammonium. There was no clear effect of fire on soil

Table 1. Comparison of Soil Chemical Characteristics for Cerrado Soils Along a

Burning Chronosequence

\begin{tabular}{|c|c|c|c|}
\hline & Unburned & Burned & Burned + 30 Days \\
\hline $\begin{array}{c}\text { Exchangeable } \mathrm{NH}_{4}+ \\
(\mathrm{mg} \mathrm{kg-soil}-1)\end{array}$ & $14.4(1.4)$ & $42.9(2.7)$ & $26.6(3.7)$ \\
\hline $\begin{array}{l}\text { Exchangeable } \mathrm{NO}_{3-}^{-} \\
\text {(mg kg-soil-1) }\end{array}$ & $11.5(1.71)$ & $14.5(1.4)$ & $5.88(1.65)$ \\
\hline $\begin{array}{l}\text { Exchangeable } \mathrm{NO}_{2-}^{-} \\
\left.\text {(mg kg-soil }{ }^{-1}\right)\end{array}$ & $0.64(0.13)$ & $0.57(0.06)$ & $0.63(0.29)$ \\
\hline $\mathrm{pH}$ & $3.74(0.50)$ & $4.17(0.04)$ & $3.88(0.02)$ \\
\hline Total N (\%) & $0.260(0.012)$ & $0.320(0.009)$ & $0.283(0.015)$ \\
\hline Total C (\%) & $5.18(0.28)$ & $6.06(0.28)$ & $5.53(0.36)$ \\
\hline
\end{tabular}

Values shown are means (standard error). 
extractable $\mathrm{NO}_{2}^{-}$and $\mathrm{NO}_{3}^{-}$. Detectable concentrations of $\mathrm{NO}_{2}$ - were relatively high in all soils. Soil $\mathrm{pH}$ also increased measurably in the top $2 \mathrm{~cm}$ of the soil due to the addition of ash produced by the fire.

\section{$\mathrm{CH}_{4}$ and $\mathrm{CO}_{2}$ Fluxes}

Cerrado that is unburned has no significant flux of $\mathrm{CH}_{4}$ (Figure 1). Newly burned cerrado had a $\mathrm{CH}_{4}$ flux rate of $-0.038(\mathrm{SE}=0.029) \mu \mathrm{g}-\mathrm{C} \mathrm{m}^{-2} \mathrm{~s}^{-1}$ that increased to -0.177 ( $\mathrm{SE}=0.093) \mu \mathrm{g}-\mathrm{C} \mathrm{m}^{-2} \mathrm{~s}^{-1}$ at sites burned 30 days earlier. By 1 year after the fire, $\mathrm{CH}_{4}$ uptake by soils had disappeared. $\mathrm{CH}_{4}$ fluxes were not correlated with any soil chemical parameter (Table 2).

$\mathrm{CO}_{2}$ fluxes were higher for burned cerrado than for the unburned control (Figure 2). At sites burned 1 year earlier and at the long-term fire exclusion sites, $\mathrm{CO}_{2}$ fluxes were insensitive to water additions. In contrast, newly burned sites and sites burned 30 days earlier responded strongly to water additions. $\mathrm{CO}_{2}$ fluxes were correlated with $\mathrm{NO}$ fluxes and soil exchangeable $\mathrm{NH}_{4}{ }^{+}, \mathrm{NO}_{3}{ }^{-}$and $\mathrm{NO}_{2}^{-}$(Table 2). $\mathrm{CO}_{2}$ flux and soil temperature are not well correlated with analysis yielding a high $\mathrm{Q}_{10}$ of about five (Figure 3 ). There were no significant changes in $\mathrm{CO}_{2}$ flux with the addition of $\mathrm{NH}_{4}{ }^{+}$or $\mathrm{NO}_{3}{ }^{-}$. The nitrification inhibitors $\mathrm{C}_{2} \mathrm{H}_{2}$ and $\mathrm{ATU}$ also had no effect.

\section{NO and $\mathrm{N}_{2} \mathrm{O}$ Fluxes}

The variation in the NO fluxes measured is shown with a probability plot (Figure 4). The variance is large and apparently not normally distributed when examined across all treatments. NO fluxes from sites burned the previous

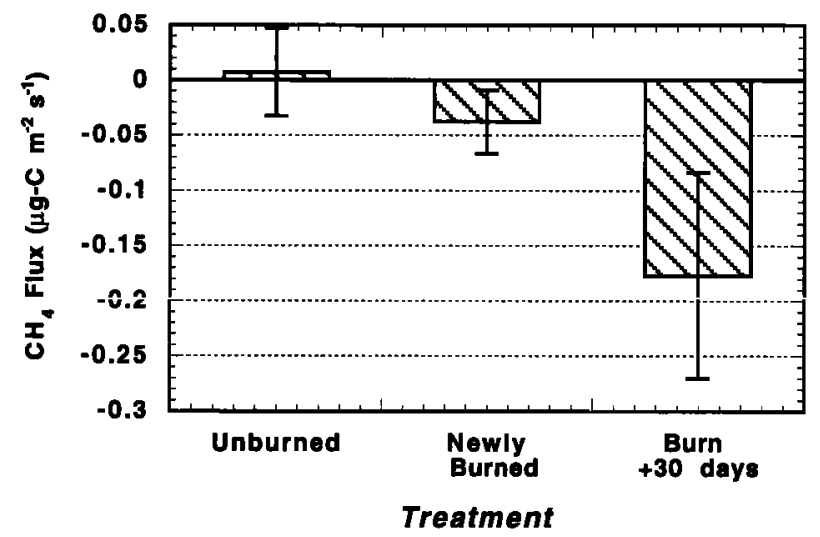

Figure 1. Methane fluxes for cerrado (tropical savanna) near Brazília, Brazil, as a function of time since burning. Values shown are means (SE). All treatments were significantly different $(p<0.05)$.

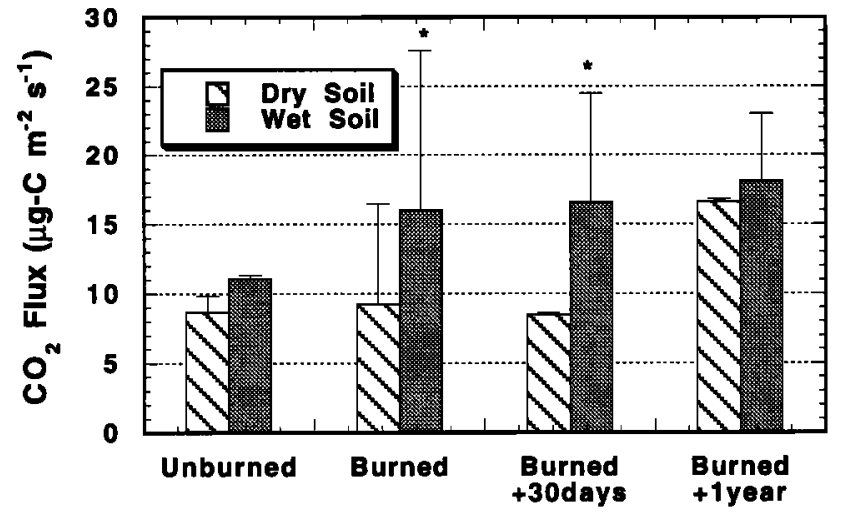

Figure 2. Carbon dioxide fluxes for cerrado (tropical savanna) near Brazília, Brazil, as a function of time since burning. Change in flux with the addition of $1 \mathrm{~cm}$ of water is shown by the gray bars (asterisk indicates a significant increase $p<0.05$ with the addition of water).

day and 1 month earlier were significantly higher than those from unburned control sites and were dramatically increased by the addition of water (Figure 5). Soil $\mathrm{N}_{2} \mathrm{O}$ fluxes were significantly higher in burned plots than unburned plots but dropped back to unburned levels within 30 days. Both $\mathrm{NO}$ and $\mathrm{N}_{2} \mathrm{O}$ fluxes were significantly correlated with $\mathrm{pH}$. Here, $\mathrm{pH}$ increases as a result of the ash deposited by burning. NO flux was also correlated with soil exchangeable $\mathrm{NH}_{4}{ }^{+}$but uncorrelated with $\mathrm{NO}_{3}{ }^{-}$and other soil chemical parameters (Figure 6 and Table 2). NO flux and temperature were poorly correlated with a $\mathrm{Q}_{10}$ of about 3.8 (Figure 3 ). $\mathrm{N}_{2} \mathrm{O}$ fluxes were weakly but significantly correlated with soil total $\mathrm{N}$ (Table 2). There were no significant changes in $\mathrm{NO}$ and $\mathrm{N}_{2} \mathrm{O}$ fluxes with the addition of $\mathrm{NH}_{4}{ }^{+}$or $\mathrm{NO}_{3}{ }^{-}$. The nitrification inhibitors $\mathrm{C}_{2} \mathrm{H}_{2}$ and ATU also had no effect.

\section{Discussion}

$\mathrm{CH}_{4}$ uptake is observable after the fire in spite of the biocidal effects of fire at the soil surface (Figure 1). Cerrado fires produce temperatures that would destroy microorganisms within the top few millimeters of the soil suiface [Dinin et al., 1985]. This amount of soil heating would only be enough to destroy a small fraction of the total soil microorganism population within the greater soil profile. Curiously, the unburned cerrado had no measurable $\mathrm{CH}_{4}$ uptake or production. This agrees with observations for tropical savanna in Venezuela [Hao et al., 1988].

There is a source of methane in cerrado soils. Burning in cerrado is done during the dry season, and these fires were carried out in the dry season. Hence there were no soil sites suitably anaerobic from water logging for methane formation. Termites are common in cerrado, and 
Table 2. Correlation Matrix (Values of $\mathbf{r}$ ) for Trace Gas Fluxes, Soil Chemical Parameters and the Most Probable Number of Soil Chemoautotrophic Ammonium Oxidizers

\begin{tabular}{|c|c|c|c|c|c|c|c|c|c|c|c|}
\hline & $\begin{array}{l}\mathrm{CO}_{2} \\
\text { Flux }\end{array}$ & $\begin{array}{l}\mathrm{CH}_{4} \\
\text { Flux }\end{array}$ & $\begin{array}{l}\mathrm{N}_{2} \mathrm{O} \\
\text { Flux }\end{array}$ & $\begin{array}{l}\text { NO } \\
\text { Flux }\end{array}$ & $\mathrm{pH}$ & $\mathrm{NH}_{4}^{+}$ & $\mathrm{NO}_{3-}^{-}$ & $\mathrm{NO}_{2}^{-}$ & Total N & Total C & MPN \\
\hline $\mathrm{CO}_{2}$ Flux & 1 & & & & & & & & & & \\
\hline $\mathrm{CH}_{4}$ Flux & 0.29 & 1 & & & & & & & & & \\
\hline $\mathrm{N}_{2} \mathrm{O}$ Flux & -0.34 & 0.27 & 1 & & & & & & & & \\
\hline NO Flux & $0.61^{*}$ & 0.13 & 0.20 & 1 & & & & & & & \\
\hline $\mathrm{pH}$ & -0.04 & -0.09 & $-0.51^{*}$ & $0.37 *$ & 1 & & & & & & \\
\hline $\mathrm{NH}_{4}^{+}$ & $0.52^{*}$ & 0.01 & -0.41 & $0.76^{*}$ & $0.76^{*}$ & 1 & & & & & \\
\hline $\mathrm{NO}_{3}-$ & $-0.46 *$ & 0.26 & 0.20 & 0.16 & 0.21 & 0.11 & 1 & & & & \\
\hline $\mathrm{NO}_{2}$ & $0.64 *$ & 0.27 & -0.35 & 0.13 & -0.01 & -0.18 & -0.06 & 1 & & & \\
\hline Total N & 0.21 & -0.22 & $-0.47^{*}$ & 0.35 & 0.26 & $0.68^{*}$ & 0.24 & -0.19 & 1 & & \\
\hline Total C & 0.11 & -0.16 & -0.42 & -0.20 & 0.05 & $0.49 *$ & 0.24 & -0.19 & $0.92 *$ & 1 & \\
\hline MPN & 0.17 & 0.12 & -0.10 & 0.16 & 0.05 & 0.09 & -0.02 & -0.07 & 0.16 & 0.06 & 1 \\
\hline Soil $\mathrm{H}_{2} \mathrm{O}$ & 0.34 & -0.21 & 0.05 & 0.30 & $-0.50^{*}$ & -0.02 & $-0.51^{*}$ & -0.40 & 0.01 & 0.10 & -0.16 \\
\hline
\end{tabular}

Significance level is * for $\mathrm{p}<0.05$.

our research site was no exception. Arboreal and surface termite nests are a very common sight. Termites, and especially tropical termites, can produce measurable quantities of $\mathrm{CH}_{4}$ [Zimmerman et al., 1982] although recent information indicates that this is a small part of the global total released to the atmosphere [Martius et al., 1993]. Termites in tropical savannas typically forage through a complex system of underground passages, and many species build underground galleries. The net effect of this dispersal of termites during food gathering would be to disperse the source of methane generation and diffusion into

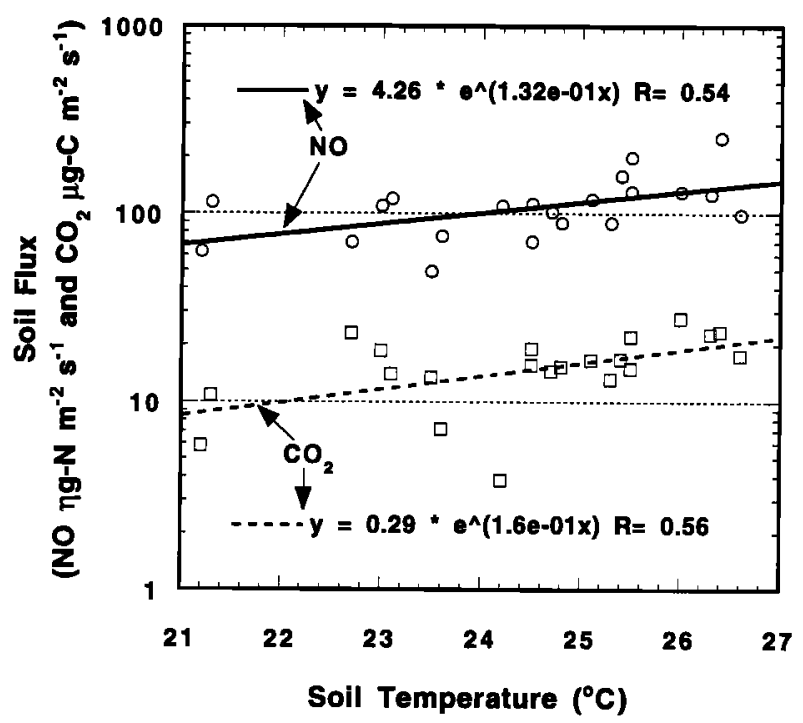

Figure 3. Relationships between soil nitric oxide and carbon dioxide fluxes and soil temperature. soil [Striegl, 1993]. We hypothesize that as a result of a decline in available food due to burning of above ground biomass, there is a decrease in termite foraging activity in burned cerrado, as has been observed with other insects [ $D e$ Olivera and Franklin, 1993]. Presumably, they focus foraging attention on unburned islands within the fire area or adjacent unburned areas. This effect is probably very transitory, since vegetation begins to regrow even before the rains arrive. While the source of $\mathrm{CH}_{4}$ is thereby reduced, the potential to oxidize $\mathrm{CH}_{4}$ will remain relatively steady; thus we would expect to observe net uptake of $\mathrm{CH}_{4}$ by burned soils. Because soil methane oxidation has been shown to be inhibited by increases in avcilable soil

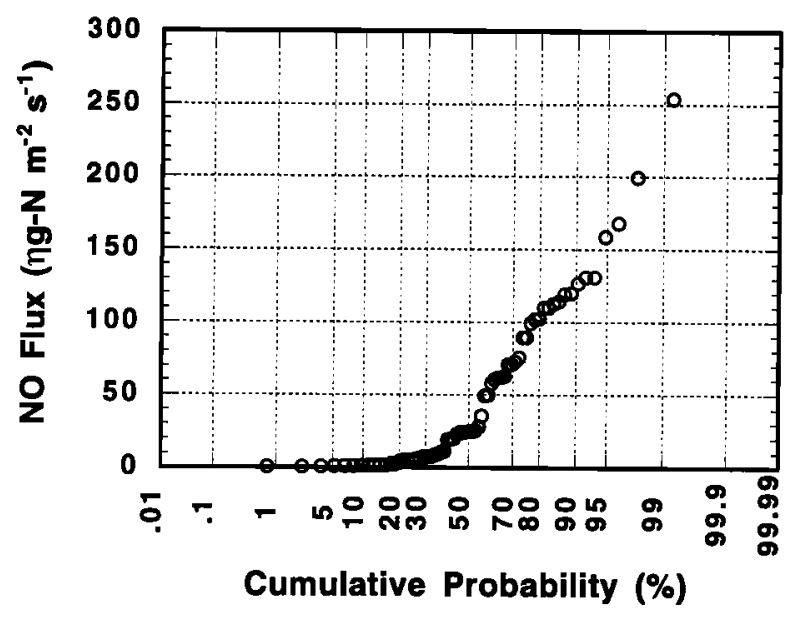

Figure 4. Probability plot of all soil nitric oxide fluxes. Note that all fluxes greater than $20 \mathrm{ng}-\mathrm{N} \mathrm{m}^{-2} \mathrm{~s}^{-1}$ are from soils that have had water added. 

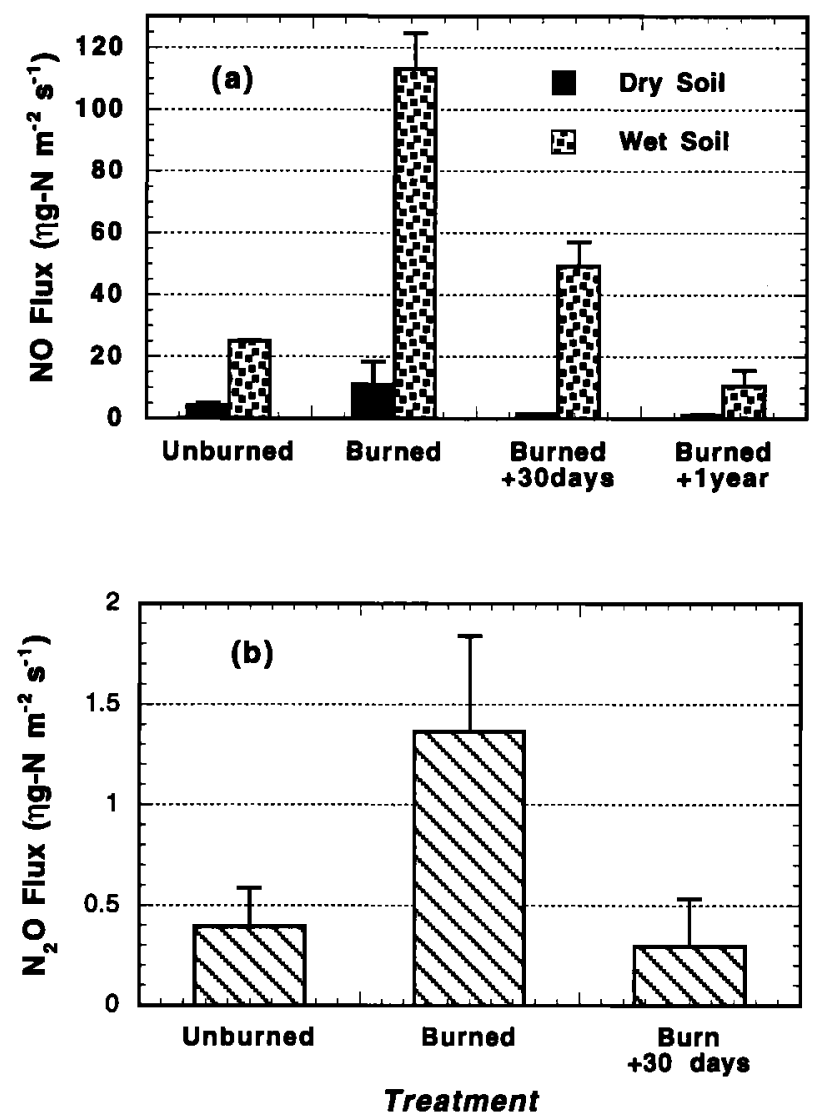

Figure 5. (a) Nitric oxide and (b) nitrous oxide fluxes for cerrado (tropical savanna) near Brazília, Brazil, as a function of time since burning. Change in NO flux with the addition of $1 \mathrm{~cm}$ of water is shown by the shaded bars. All NO fluxes were significantly higher with the addition of water $\left(\mathrm{p}<0.05\right.$ ). $\mathrm{N}_{2} \mathrm{O}$ fluxes were not significantly different with water addition and the values shown are the mean of wet and dry soil measurements.

ammonium [Mosier et al., 1991], and because soil exchangeable $\mathrm{NH}_{4}{ }^{+}$concentrations at these cerrado sites were high relative to controls (Table 1), our observations of $\mathrm{CH}_{4}$ uptake probably represent a conservative measure of the overall $\mathrm{CH}_{4}$ oxidation rate for these soils. This uptake is probably observable only when termite foraging has been dramaticaily reduced or redirected to unburned areas for a brief period before vegetation begins regrowing. New plant growth is observable within days.

The absence of uptake by unburned cerrado soils indicates the presence of an equilibrium between the source of soil methane, presumably the foraging termite community, and the sink for methane, oxidation by the soil microflora [Seiler et al., 1984]. Although this is the case for soils, it may not be the case for termite nests. The larger populations of termites in nests do produce measurable fluxes from the nests [Martius et al., 1993].
To evaluate the importance of tropical soil $\mathrm{CH}_{4}$ uptake, we need to project our observed rates at this one site to all tropical soils. If we extrapolate the observed methane uptake rate for soils at the burned site of $0.038(\mathrm{SE}=0.029)$ $\mu \mathrm{g} \mathrm{m}^{-2} \mathrm{~s}^{-1}$ to all tropical savanna soils $\left(15 \times 10^{12} \mathrm{~m}^{2}\right)$, we calculate a total uptake of $18 \mathrm{Tg} \mathrm{CH}_{4} \mathrm{y}^{-1}$. This is $70 \%$ of the estimated global total termite methane emission of $26 \mathrm{Tg} \mathrm{CH}_{4}-\mathrm{C} \mathrm{y}^{-1}$ [Martius et al., 1993]. It is speculative to extend our results from one site to all tropical savannas as we have done above. Certainly, further work will be required to verify $\mathrm{CH}_{4}$ uptake by tropical savanna soils. If our hypothesis concerning termite induced $\mathrm{CH}_{4}$ oxidation by soils is correct, then unburned soils should demonstrate strong $\mathrm{CH}_{4}$ oxidation in a laboratory setting.

An alternative hypotheses might explain the uptake of $\mathrm{CH}_{4}$ by burned soils. Burning might increase the diffusion of $\mathrm{CH}_{4}$ into the soil, and hence $\mathrm{CH}_{4}$ oxidation, by opening root channels and removing litter layers. If $\mathrm{CH}_{4}$ oxidation is diffusion limited, then removing plants and litter layers
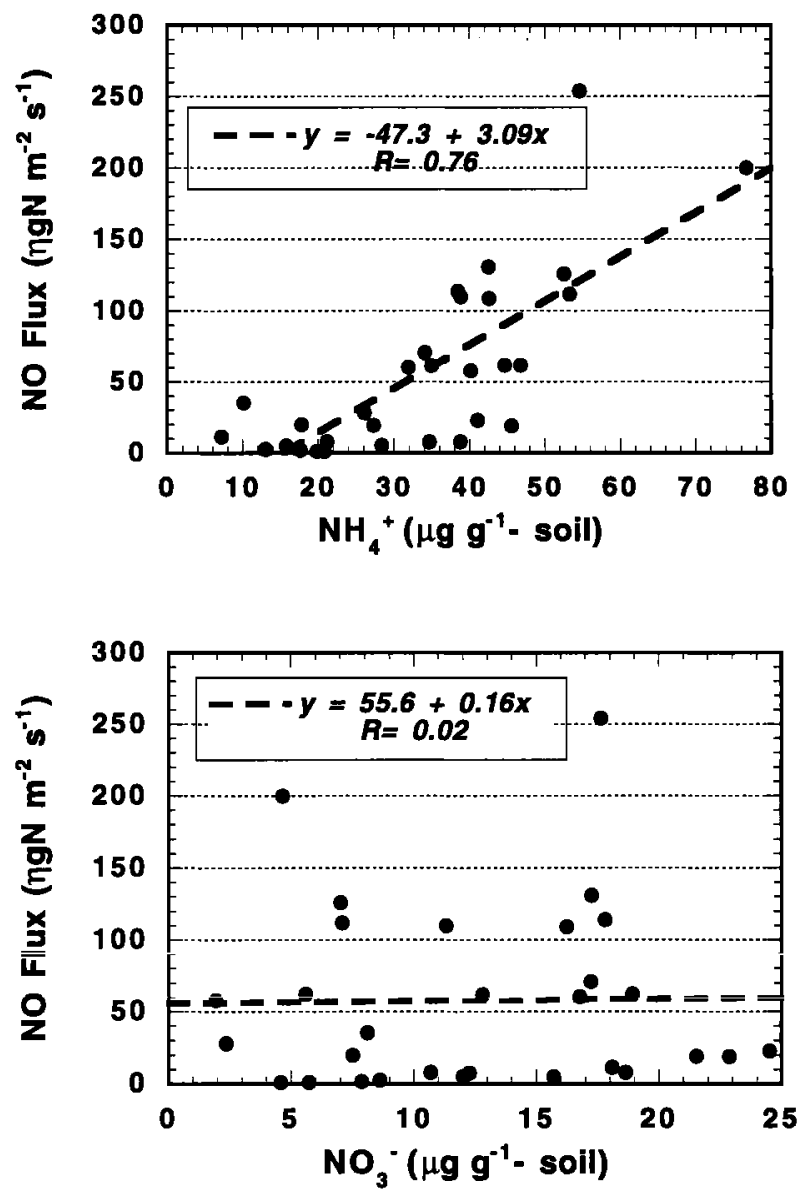

Figure 6. Relationships between soil $\mathrm{KCi}$ extractable ammonium and nitrate and soil nitric oxide flux for cerrado (tropical savanna) near Brazília, Brazil. The relationship for ammonium is significant $(\mathrm{p}<0.05)$. 
in the field (perhaps by raking away litter and clipping plants) should increase diffusion to the soil and increase $\mathrm{CH}_{4}$ oxidation.

$\mathrm{CO}_{2}$ fluxes were up to 30 times higher that those reported for tropical savanna in Venezuela [Hao et al., 1988] but were comparable to rates observed in Florida pine plantations [Castro et al., 1994] and California Chaparral [Anderson and Poth, 1989]. Fire increased emissions $(p=0.057)$ when low water availability did not limit soil microbial activity (Figure 2). The effects of fire in elevating $\mathrm{CO}_{2}$ fluxes were very persistent, lasting for a year. Burning may have longer lasting effects than other anthropogenic disturbances that stimulate emissions, like fertilization [Castro et al., 1994; Matson et al., 1992]. Fertilization initially increases available $\mathrm{N}$ and so may stimulate $\mathrm{C}$ mineralization and associated $\mathrm{CO}_{2}$ fluxes briefly. Fire, on the other hand, by killing plants, eliminates initial plant competition for $\mathbf{N}$ and leaves partially burned plant material and roots available for decomposition. Fire may indirectly make soil organic matter more available for microbial decomposition as a result of the rise in soil $\mathrm{pH}$. This could be a consequence of the greater solubility of humic and fulvic acids at higher $\mathrm{pH}$ [Schnitzer, 1982]. The net result of all of these factors combined may be a more persistent temporal effect on $\mathrm{C}$ mineralization. The effects of fire on $\mathrm{C}$ mineralization and $\mathrm{CO}_{2}$ flux were much more persistent that on NO flux that had returned to control levels 1 year after the fire. The difference may be due to the more persistent supply of $\mathrm{C}$ for mineralization and reestablishment of the plant community and a decrease in the availability of soil $\mathrm{N}$.

NO flux in cerrado is correlated with $\mathrm{NH}_{4}{ }^{+}$availability (Table 2) as in other wildland and agricultural ecosystems [Papen et al., 1993; Sanhueza et al., 1990; Shepherd et al., 1991]; yet, addition of $\mathrm{NH}_{4}+$ did not significantly increase NO flux rates at the unburned site. Our MPN determinations isolated chemoautotrophic nitrifiers from cerrado soils. The substrate for chemoautrophic nitrifiers is ammonia rather than ammonium ion. This is a result of the specificity of the ammonia oxidizing enzyme for ammonia [Suzuki et al., 1974] and the much better transport of ammonia rather than ammonium into bacterial cells [Kleiner, 1985]. The stimulation of NO fluxes at the burned site may be due to the key combination of increased soil $\mathrm{NH}_{4}^{+}$, providing substrate, and increased soil $\mathrm{pH}$. The result is greater $\mathrm{NH}_{3}$ uptake by nitrifiers and more nitrification and associated trace gas production.

Nitrifiers were the apparent source of $\mathrm{N}$ trace gas emissions. $\mathrm{C}_{2} \mathrm{H}_{2}$ and ATU, both inhibitors of nitrification, failed to reduce $\mathrm{N}$ trace gas fluxes. Though wellknown inhibitors of autotrophic nitrification, these inhibitors will be far less effective if the nitrifiers in these acidic soils are heterotrophic [Anderson et al., 1993] rather than acid tolerant autotrophic strains [Martikainen and De Boer, 1993]. Alternatively, the ineffectiveness of inhibitors may be due to the coupling of nitrifier production of $\mathrm{NO}_{2}{ }^{-}$ to the chemodenitrification of this product to NO. If the pool of soil $\mathrm{NO}_{2}$ - is large enough, chemodenitrification may not decrease immediately upon the addition of a nitrification inhibitor [Davidson, 1993]. Evidence that nitrification is the source of $\mathrm{N}$ trace gases includes the higher $\mathrm{NO}$ and $\mathrm{N}_{2} \mathrm{O}$ fluxes in response to burning which increases soil $\mathrm{pH}$ and $\mathrm{N}$ availability, conditions that favor nitrifiers. The high NO: $\mathrm{N}_{2} \mathrm{O}$ ratio of about 50 between these fluxes reflects generally aerobic conditions [Davidson, 1993]. Since soils remained aerobic and there was no correlation between $\mathrm{N}$ trace gas fluxes and soil nitrate, we conclude that there was no heterotrophic denitrification producing $\mathrm{N}$ trace gases. The $\mathrm{Q}_{10}$ values for both $\mathrm{NO}$ and $\mathrm{CO}_{2}$ soil emissions after wetting are high, and the linearity of the relationship with temperature was poor (Figure 3). This is probably due to the number of interacting biological and physical factors involved and is indicative of changing conditions. As a result, models of biogenic trace gas fluxes from soil should carefully consider other variables such as soil moisture.

The mean NO flux (113 ng-N m-2 $\mathrm{s}^{-1}$, Figure 5a) from cerrado soils after fire and with the addition of water is among the highest ever observed. We used our data on emission rate changes with time after burning and with and without water limitations to calculate and estimate the annual emission of NO from cerrado. We assumed that the rainy season in the cerrado lasts for 6 months and that the frequency of burning is 2 years. For both the wet and the dry seasons, mean daily fluxes, as displayed in Figure 5a, at the newly burned site were assumed to last for 14 days and fluxes at the month-old burn for 30 days. Wet and dry rates from unburned cerrado were used for the remainder of the wet and dry seasons, respectively.

The total NO emission observed is high relative to fluxes from other ecosystems (Table 3). The calculation of regional and ecosystem emissions is very problematic [Keller and Goldstein, 1994]: to compare the relative importance of direct fire emissions with subsequent biogenic emissions from soil, we extended our results to all tropical savanna. On the basis of this tentative extension of our data, post-fire soil emissions of NO (3.9 $\left.\operatorname{Tg~} \mathrm{y}^{-1}\right)$ nearly equal direct emissions during fire $\left(4.4 \mathrm{Tg} \mathrm{y}^{-}\right.$ 1, Table 3). The magnitude and importance of biogenic emissions in tropical savannas will need to be confirmed by other studies, preferably at other sites.

Biogenic emissions from post-fire soils will have much different temporal and spatial distributions than emissions during burning. Direct emissions of NO from fire will end with the arrival of the rainy season. Biogenic emissions that have been water limited during the dry season, when fires are most abundant, will peak during the early part of 
Table 3. Global Annual Emissions of $\mathrm{NO}$ and $\mathrm{N}_{2} \mathrm{O}$ from Burned and Unburned Ecosystems

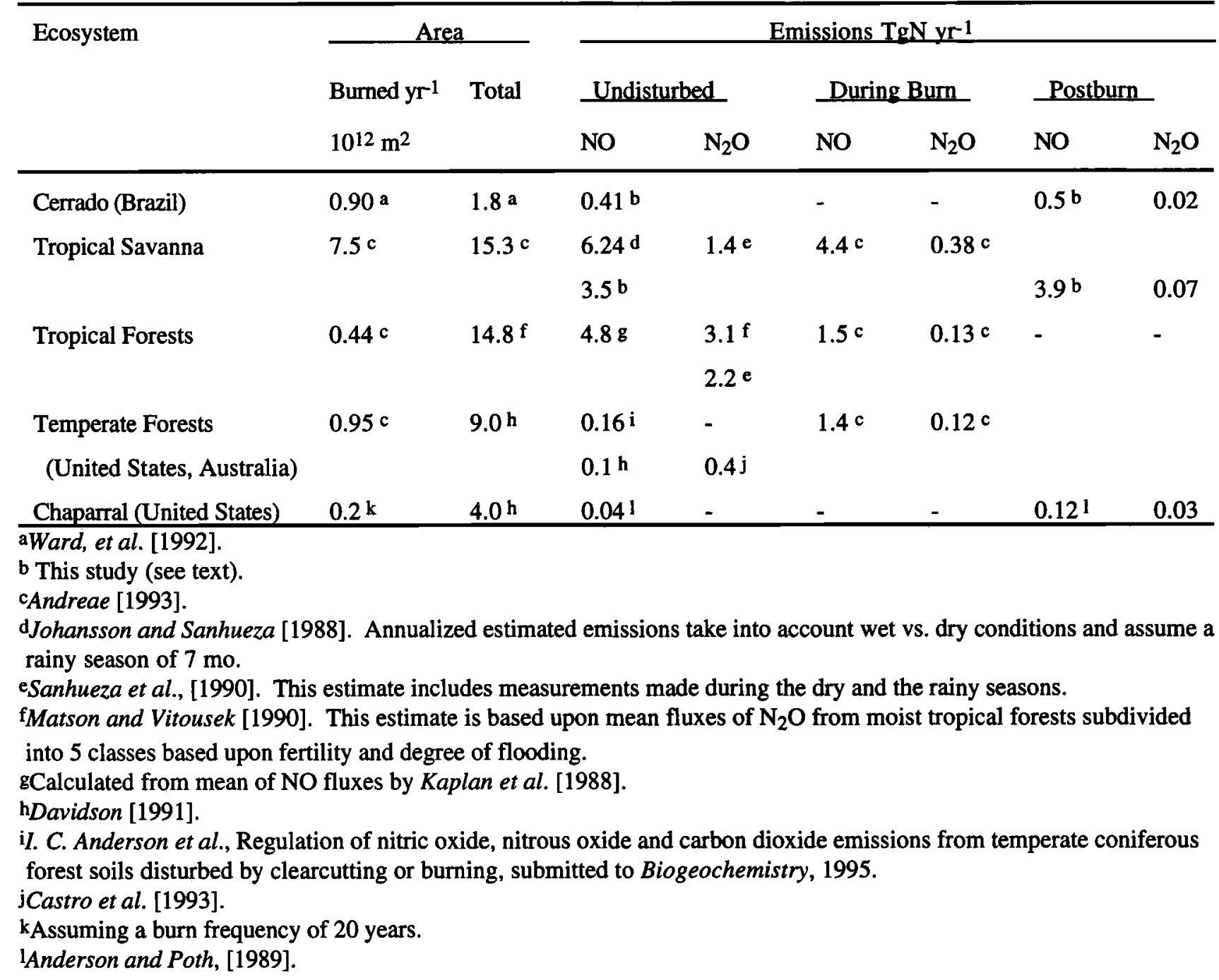

the wet season. The peak of soil NO emissions just at the start of the rainy season may help sustain conditions for ozone formation by providing NO just as the direct source from fire is waning. This chain of events may partially explain observations of sustained high ozone concentrations in the tropics [Delaney et al., 1985].

The importance of tropical savannas, like the cerrado, as significant global sources of NO is becoming clear [Davidson, 1991, Levine et al., 1995]. The mean soil emissions of NO observed in this study are among the highest observed for any ecosystem thus far studied (Table 3). Emissions of NO from tropical systems appear to be much greater than from temperate ecosystems, agroecosystems, and boreal ecosystems.

In summary, we have provided some of the first information on the flux of trace gases from tropical savanna soils in Brazil. An assessment of our data suggests that tropical savanna, burned or unburned, is a major source of NO to the troposphere. Cerrado appears to be a minor source of $\mathrm{N}_{2} \mathrm{O}$ and a sink for atmospheric $\mathrm{CH}_{4}$.
Burning also elevated $\mathrm{CO}_{2}$ fluxes, which remained detectably elevated 1 year later. It is clear that fire is important in regulating the exchange of trace gases between cerrado soils and the atmosphere.

Acknowledgments. We are grateful for the financial support provided for this work by the USDA - Forest Service, Pacific Global Change Research Program, the Universidade de Brasília (UnB) and the Conselho Nacional de Deseñvoivimentio Científico \& Tecnológice (CNPq). Invaluable assistance was provided by Diane Bellis, Robert Glaubig, and the Director, Staff and Fire Brigade of the IBGE reserve. Helpful comments were provided by Eric Davidson, Michael Keller and an anonymous reviewer.

\section{References}

Anderson, I. C., and J. S. Levine,Simultaneous field measurements of biogenic emissions of nitric oxide and nitrous oxide, J. Geophys. Res. 92, 956-976, 1987. 
Anderson, I. C., and M. A. Poth, Semiannual losses of nitrogen as $\mathrm{NO}$ and $\mathrm{N}_{2} \mathrm{O}$ from unburned and burned chaparral, Global Biogeochem. Cycles, 3(2), 121-135, 1989.

Anderson, I. C., M. A. Poth, J. Homstead, and D. J. Burdige, A comparison of $\mathrm{NO}$ and $\mathrm{N}_{2} \mathrm{O}$ production by the autotrophic nitrifier, Nitrosomonas europaea and the heterotrophic nitrifier, Alcaligenes faecalis, Appl. Environ. Microbiol. 59, 3525-3533, 1993.

Andreae, M. O., The influence of tropical biomass burning on climate and the atmospheric environment in Chapman and Hall, Biogeochemistry of Global Change: Radiatively Active Trace Gases edited by R. S. Ormland, pp. 113-150, New York, 1993.

Castro, M. S., P. A. Steudler, J. M. Melillo, J. D. Aber, and $\mathrm{S}$. Millham, Exchange of $\mathrm{N}_{2} \mathrm{O}$ and $\mathrm{CH}_{4}$ between the atmosphere and soils in spruce-fir forests of the northeastern United States, Biogeochemistry, 18, 119$135,1993$.

Castro, M. S., W. T. Peterjohn, J. M. Melillo, P. A. Steudler, H. L. Gholz, and D. Lewis, Effects of nitrogen fertilization on the fluxes of $\mathrm{N}_{2} \mathrm{O}, \mathrm{CH}_{4}$, and $\mathrm{CO}_{2}$ from soils in Florida slash pine plantations, Can. J. For. Res., 24, 9-13, 1994.

Coutinho, L. M., Ecological effects of fire in the Brazilian cerrado, in Ecology of Tropical Savannas edited by B. J. Huntley and B. H. Walker, Springer-Verlag, pp. 273-291, New York, 1982.

Crutzen, P. J., and M. O. Andreae, Biomass burning in the tropics: Impact on atmospheric chemistry and biogeochemical cycles, Science 250, 1669-1678, 1990.

Davidson, E. A., Fluxes of nitrous oxide and nitric oxide from terrestrial ecosystems, in Microbial Production and Consumption of Greenhouse Gases: Methane, Nitrogen Oxides, and Halomethanes, edited by Amer. Soc. of Microbiol., J. E. Rogers and W. B. Whitman, pp. 219-235, Washington, D.C., 1991

Davidson, E. A., Soil water content and the ratio of nitrous oxide to nitric oxide emitted from soil in Chapman and Hall, Biogeochemistry of Global Change: Radiatively Active Trace Gases, edited by R. S. Ormland, pp. 369386, New York, 1993.

Davidson, E. A., P. A. Matson, P. M. Vitousek, R. Riley, K. Dunkin, G. Garcia-Mendez, and J. M. Maass, Processes regulating soil emissions of $\mathrm{NO}$ and $\mathrm{N}_{2} \mathrm{O}$ in a seasonally dry tropical forest, Ecology, 74, 130-139, 1993.

Delaney, A. C., P. Haagensen, S. Walters, A. F. Watrburg, and P. J. Crutzen, Photochemically produced ozone in the emission from large scale vegetation fires, J. Geophys. Res., 90(D1), 2425-2429, 1985.

De Olivera, E. P., and E. Franklin, The effect of fire on soil mesofauna: Recolonization of burnt areas, Pesq. Agropec. Bras., 28, 357-369, 1993.
Dunn, P. H., D. R. Reynolds, M. Poth, and S. C. Barro, Effects of fire on soil microflora in the tropics, Proceedings of the silver jubilee symposium, International Society for Tropical Ecology, edited by Chowk, Bhargava Book Depot, 295-301, Varanasi, India, 1985

Garcia-Mendez, G., J. M. Maass, P. A. Matson, and P. Vitousek, Nitrogen transformations and nitrous oxide flux in a tropical deciduous forest in Mexico, Oecologia, 88, 362-366, 1991.

Goodland, R. L., A physiognomic analysis of the 'cerrado' vegetation of central Brazil, J. Ecol. 59, 411-419, 1971.

Goreau, T. J., and W. Z. de Mello, Tropical deforestation: Some effects on atmospheric chemistry, Ambio, 17, 275-281, 1988.

Groffman, P. M., C. W. Rice, and J. M. Tiedje, Denitrification in a tallgrass prairie landscape, Ecology, 74 (3), 355-862, 1993.

Hao, W. M., D. Scharffe, P. J. Crutzen, and E. Sanhueza, Production of $\mathrm{N}_{2} \mathrm{O}, \mathrm{CH}_{4}$, and $\mathrm{CO}_{2}$ from soils in the tropical savanna during the dry season, J. Atmos. Chem. 7, 93-105, 1988.

Johansson, C., and E. Sanhueza, Emission of NO from Savanna Soils during rainy season, J. Geophys. Res. 93(D11), 14,193-14,198, 1988.

Kaplan, W. A., S. C. Wofsy, M. Keller, and J. M. da Costa, Emission of $\mathrm{NO}$ and deposition of $\mathrm{O}_{3}$ in a tropical forest system, J. Geophys. Res. 93, 1389-1395, 1988.

Keeney, D. R., and D. W. Nelson, Nitrogen - Inorganic Forms in Methods of Soil Analysis, 2nd. ed, Agron. Soc. Amer., Madison, Wisc., edited by A.L. Page, R. H. Miller, and D. R. Keeney, pp. 643-693, 1982.

Keller, A. A., and R. A. Goldstein, Propagation of uncertainty in carbon emission scenarios through the global carbon cycle, World Res. Rev., 6, 304-315, 1994.

Keller, M., et al., Tropical land use change and trace gas emissions, Ecol. Bull., 42, 156-163, 1992.

Keller, M., T. J. Goreau, S. C. Wofsy, W. A. Kaplan, and M. B. McElroy, Production of nitrous oxide and consumption of methane by forest soils, Geophys. Res. Lett. 10, 1156-1159, 1983.

Keller, M., W. A. Kaplan, and S. C. Wofsy, Emissions of $\mathrm{N}_{2} \mathrm{O}, \mathrm{CH}_{4}$ and $\mathrm{CO}_{2}$ from tropical forest soils, $J$. Geophys. Res., 91, 11,791-11,802, 1986.

Kleiner, D., Bacterial ammonium transport, FEMS Microbiol. Rev., 32, 87-100, 1985.

Levine, J. S., W. R. Cofer, D. R. Cahoon, and E. L. Winstead, Biomass burning a driver for global change, Environ. Sci. Technol., 29, 120-125. 1995.

Luizao, F., P. Matson, G. Livingston, R. Luizao, and P. Vitousek, Nitrous oxide flux following tropical land 
clearing, Global Biogeochem. Cycles, 3, 281-285, 1989.

Martikainen, P. J., and W. De Boer, Nitrous oxide production and nitrification in acid soil from a dutch coniferous forest, Soil Biol Biochem., 25, 343-347, 1993.

Martius, C., R. Wassmann, U. Thein, A. Banderia, H. Rennenberg, W. Junk, and W. Seiler, Methane emissions from wood feeding termites in amazonia, Chemosphere, 26, 623-632, 1993.

Matson, P. A., and P. M. Vitousek, Ecosystem approach to a globalnitrous oxide budget, BioScience, 19, 228235, 1990.

Matson, P. A., T. G. Stith, C. Volkmann, C. Billow, and C. C. Grier, Soil nitrogen cycling and nitrous oxide flux in a Rocky Mountain Douglas-fir forest: Effects of fertilization, irrigation and carbon addition, Biogeochemistry, 18, 101-117, 1992.

Mosier, A., D. Schimel, D. Valentine, K. Bronson, and W. Parton, Methane and nitrous oxide fluxes in native, fertilized and cultivated grasslands, Nature, 350. 330-332, 1991.

Papen, H., B. Hellmann, H. Papke, and H. Rennenberg, Emission of $\mathrm{N}$-oxides from acid irrigated and limed soils of a coniferous forest in Bavaria, in Chapman and Hall, Biogeochemistry of Global Change: Radiatively Active Trace Gases, edited by R. S. Oremland, pp. 245260, New York, 1993

Riggan, P. J., J. A. Brass, and R. N. Lockwood, Assessing fire emissions from tropical savanna and forests of central Brazil, Photogramm. Eng, Remote Sens., 59, 1009-1015, 1993.

Rudd, J. W. M., R. Harris, C. A. Kelly, and R. E. Hecky, Are hydroelectric reservoirs significant sources of greenhouse gasses?, Ambio, 22, 246-248, 1993.

Sanhueza, E. W., M. Hao, D. Scharfe, L. Donoso, and P. J. Crutzen, $\mathrm{N}_{2} \mathrm{O}$ and $\mathrm{NO}$ emissions from soils of the northern part of the Guayana Shield, Venezuela, $J$. Geophys. Res. 95(D13), 22,481-22,488, 1990.

Schmidt, E. L., and L. W. Belser, Nitrifying Bacteria, in Methods of Soil Analysis, edited by A. L. Page, R. H. Miller, and D. R. Keeney, pp. 1027-1042, Agron. Soc. of Am., Madison, Wisc., 1982.

Schnitzer, M., Organic Matter Characterization, in Methods of Soil Analysis, edited by A. L. Page, R. H. Miller, and D. R. Keeney, pp. 581-593, Agron. Soc. of Am., Madison, Wisc., 1982.
Seiler, W., and R. Conrad, Contributions of tropical ecosystems to the global budget of trace gases especially $\mathrm{CH}_{4}, \mathrm{H}_{2}, \mathrm{CO}$ and $\mathrm{N}_{2} \mathrm{O}$, in The gleophysiology of Amazonia, edited by R. E. Diakenson, pp. 133-160, John Wiley, New York, 1987.

Seiler, W., R. Conrad, and D. Scharffe, Field studies of methane emission from termite nests into the atmosphere and measurements of methane uptake by tropical soils, J. Atmos. Chem., 1, 171-186, 1984.

Shepherd, M. F., S. Barzetti, and D. R. Hastie, The production of atmospheric $\mathrm{NO}_{\mathrm{x}}$ and $\mathrm{N}_{2} \mathrm{O}$ from a fertilized agricultural soil, Atmos.Environ., 25A9, 1961-1969, 1991.

Striegl, R. G., Diffusional limits to the consumption of atmospheric methane by soils, Chemosphere, 26, 715-720, 1993.

Suzuki, I., U. Dular, and S. C. Kwok, Ammonia or ammonium ion as substrate for oxidation by Nitrosomonas europaea cells and extracts, J. Bacteriol., 120, 556-558, 1974.

Ward, D. E., R. A. Susott, J. B. Kaufman, R. E. Babbit, D. L. Cummings, B. Dias, B. N. Holben, Y. J. Kaufman, R. A. Rasmussen, and A. W. Setzer, Smoke and fire characteristics for cerrado and deforestation burns in Brazil: BASE-B experiment, J. Geophys. Res., 97, 14,601-14,619, 1992.

Wilkinson, L., SYSTAT: The System for Statistics, SYSTAT, Inc., Evanston, Ill., 1989.

Zimmerman, P. R., J. P. Greenberg, S. O. Wandinga, and P. J. Crutzen, Termites: A potentially large source of atmospheric methane, carbon dioxide, and molecular hydrogen, Science, 218, 563-565, 1982.

I. Cofman Anderson, Virginia Institute of Marine Science, College of William and Mary, P.O. Box 1346, Gloucester Point, VA 23062. (e-mail: iris@merlin.bio.vims.edu)

H. Sinatora Miranda and A. C. Miranda, Departamento do Ecológia, Universidade de Brasília, 70910-900, Brasilia, D.F. Brasil. (e-mail: h.miranda@guarany.cpd.unb.br; a.miranda@guarany.cpd.unb.br)

M. Poth and P. J. Riggan, USDA Forest Service Research, 4955 Canyon Crest Drive, Riverside, CA 92507. (e-mail: $/ \mathrm{s}=3 \mathrm{~d} \mathrm{~m}$. poth $/ \mathrm{oul}=3 \mathrm{ds} 27 \mathrm{~L} 05 \mathrm{a} @ \mathrm{mhs} \#$ fsbo. attmail.com, /s=3dp.riggan/ou1=3ds27L05a@mhs\#fsbo.attmail.com)

(Received November 30, 1994; revised June 30, 1995; accepted July 5, 1995.) 